\title{
Copepod feeding stimulates bacterioplankton activities in a low phosphorus system
}

\author{
Josefin Titelman $^{1, *, * *}$, Lasse Riemann ${ }^{2, * *}$, Karin Holmfeldt ${ }^{2}$, Trygve Nilsen ${ }^{3}$ \\ ${ }^{1}$ Department of Marine Ecology, University of Göteborg, Kristineberg 566, 45034 Fiskebäckskil, Sweden \\ ${ }^{2}$ Department of Natural Sciences, Kalmar University, 39182 Kalmar, Sweden \\ ${ }^{3}$ Department of Mathematics, University of Bergen, PO Box 7800, 5020 Bergen, Norway
}

\begin{abstract}
Zooplankton sloppy feeding releases high-quality dissolved organic matter, which is readily used by microbes. We hypothesized that in phosphorus (P) limited environments, released dissolved DNA may be a particularly important source of P for bacteria. In an incubation experiment with water from the Bothnian Bay, Sweden, we investigated the short-term effect of copepod feeding activity on bacterial production, DNA uptake and phosphatase activity. Consistent patterns in bacterial activity measures suggested that copepod feeding activity stimulated phosphatase activity, DNA uptake and production. The P taken up as dissolved DNA exceeded cellular P requirements. We speculate that bacterioplankton cells in the Bothnian Bay store excess P intracellularly during times of extensive sloppy feeding, which may then subsequently be utilized to prevent $\mathrm{P}$ limitation of growth.
\end{abstract}

KEY WORDS: Bacteria $\cdot$ Copepod $\cdot$ DNA uptake $\cdot$ Phosphorus $\cdot$ Alkaline phosphatase $\cdot$ Dissolved DNA · Bothnian Bay

- Resale or republication not permitted without written consent of the publisher

\section{INTRODUCTION}

Pelagic food webs are often complex, with many direct interactions between organisms, as well as indirect connections, for example, through trophic cascades initiated by predator activities (e.g. Stibor et al. 2004). This implies that dynamics of animals and microbes within pelagic food webs are often linked (e.g. Jumars et al. 1989), for instance, through the generation of bioavailable dissolved organic matter (DOM) by animal activity (e.g. Hansson \& Norrman 1995, Møller et al. 2003) or death (e.g. Titelman et al. 2006).

Zooplankters contribute substantial amounts of DOM to the environment through sloppy feeding (e.g. Lampert 1978, Strom et al. 1997) and by excretion and leakage from their fecal pellets (e.g. Jumars et al. 1989, Urban-Rich 1999). The extent of sloppy feeding depends on the predator:prey size ratio (Møller 2005, 2007) and probably also on prey morphology. Although highly variable (reviewed in Møller 2005), as much as 60 to $95 \%$ of the particulate organic carbon (POC) removed from suspension may be returned to the surroundings through sloppy feeding (Roy et al. 1989, Møller \& Nielsen 2001). DOM leakage from fecal pellets and sedimentation represents smaller losses (Møller et al. 2003).

The importance of sloppy feeding as a resource for the microbial food web depends on the quality of the DOM produced and on the nutrient limitations of the bacteria. Several authors have traced incorporation of copepod(e.g. Møller \& Nielsen 2001) and jellyfish-produced (e.g. Hansson \& Norrman 1995) dissolved organic carbon (DOC) into bacterial growth. In contrast, few studies consider other quality aspects of zooplankton-produced DOM (but see e.g. Hasegawa et al. 2001), despite its potential importance in nutrient-limited systems.

$\mathrm{P}$ limitation is common in both limnetic and marine environments, including oligotrophic parts of the Mediterranean (Zohary \& Robarts 1998) and the North Pacific (Björkman \& Karl 2003), as well as the Bothnian 
Bay (Kuparinen et al. 1996). In such environments zooplankton may be considered nutrient sinks (Pertola et al. 2002), while smaller phytoplankton and protist prey represent potential sources of $\mathrm{P}$ that may become available to bacterioplankton through sloppy feeding by zooplankters. Thus, by releasing readily accessible DOM, including dissolved organic phosphorus (DOP), zooplankters effectively contribute to the microbial regeneration of nutrients. Because dissolved DNA (D-DNA) contains a large amount of P ( 10\% weight per weight), it may contribute substantially to the DOP pool. For example, D-DNA accounts for $\sim 7 \%$ of the DOP in Tampa Bay (Paul et al. 1988). In seawater, D-DNA is typically available at concentrations of $\sim 0.2$ to $19 \mathrm{\mu g} \mathrm{l}^{-1}$ (DeFlaun et al. 1987) and plays a significant part in the overall turnover of $P$ (Paul et al. 1988). D-DNA dynamics are driven by primary production (Paul et al. 1988, Siuda et al. 1998), but are also linked to food web interactions such as flagellate and ciliate grazing (Turk et al. 1992, Alonso et al. 2000) and viral lysis (Brum 2005). Similarly, grazing of larger zooplankters may add to D-DNA dynamics. D-DNA has rapid turnover rates, especially in eutrophic marine systems (<1 di Paul et al. 1987) and may supply both energy and nutrients for bacterioplankton growth. For instance, D-DNA uptake may provide up to $5-10 \%$ of bacterial $\mathrm{C}$ and $\mathrm{N}$ requirements (Jørgensen \& Jacobsen 1996), but may be even more important as a $\mathrm{P}$ source, particularly in low $\mathrm{P}$ environments (Turk et al. 1992).

The Bothnian Bay represents the northern-most part of the Baltic Sea and is separated from the central Baltic Sea by a shallow sill that limits exchange of water and nutrients. During the dark winter the Bothnian Bay is ice covered for several months. From spring to autumn the large inflow of river-borne DOM, poor in $\mathrm{P}$ (Kuparinen et al. 1996), provides energy and nutrients for the planktonic food web, where bacterioplankton dominate C consumption (Sandberg et al. 2004). However, the bacterial growth is generally $\mathrm{P}$ limited, especially in summer (Zweifel et al. 1995). In the present study we experimentally examined if copepod grazing activity, known to produce bioavailable C (Møller \& Nielsen 2001), could stimulate bacterial activity in water from the P-limited Bothnian Bay by supplying bioavailable organic $\mathrm{P}$. We focused on bacterial responses in growth, DNA uptake and enzymatic activity.

\section{METHODS}

Experimental setup. We monitored bacterial activity as a function of copepod grazing activities in water from the Bothnian Bay. The experiment was carried out at the Umeå Marine Sciences Centre (Hörnefors, Sweden) in June 2006, at approximate in situ light (20 h light, $4 \mathrm{~h}$ darkness), temperature $\left(\sim 9^{\circ} \mathrm{C}\right)$ and salinity $(\sim 3 \%)$ conditions. The general setup is shown in Fig. 1, and details of the various steps involved are given under separate subheadings below. The experiment consisted of 2 steps; an 'exposure' step and an 'incubation' step defined as follows (Fig. 1). Water inoculated with indigenous bacteria was first exposed to combinations of \pm copepods, and \pm phytoplankton for $\sim 1 \mathrm{~h}$ ('exposure'), after which copepods and phytoplankton were removed ('filtration') and the filtrate was incubated for $24 \mathrm{~h}$ ('incubation') (Fig. 1). All equipment was acid washed prior to use.

Water collection: On the day of the experiment phytoplankton, bacteria and water for incubation were collected outside Norrbyskär, Bothnian Bay, Sweden $\left(63^{\circ} 34.29^{\prime} \mathrm{N}, 19^{\circ} 54.50^{\prime} \mathrm{E}\right)$ at 2 to $7 \mathrm{~m}$ depth using $10 \mathrm{l}$ Hydrobios water samplers. Water was transported to the laboratory in 251 containers.

Preparation of exposure solutions: To detect bacterial responses in short-timescale exposures, it is necessary to use high concentrations of both copepods and phytoplankton, with low starting concentrations of bacteria (cf. Møller \& Nielsen 2001). Therefore, to obtain appropriate concentrations for the 2 phytoplankton treatments ('copepods + phytoplankton',

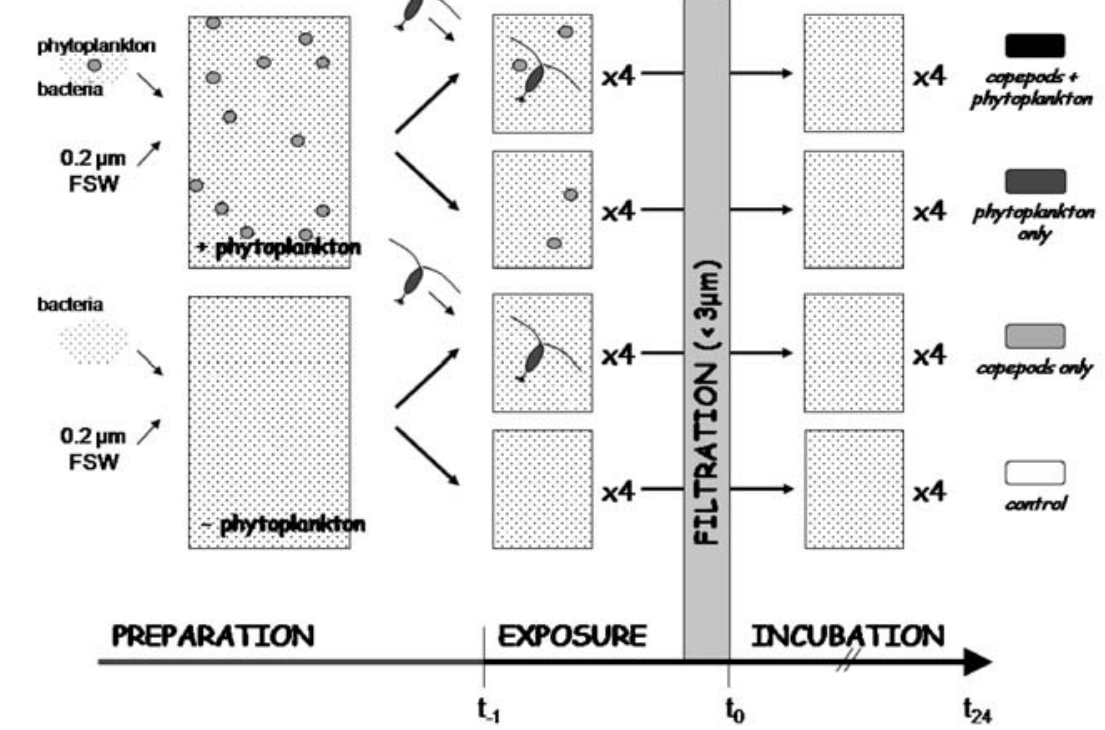

Fig. 1. Schematic presentation of experimental preparation and setup, and definition of experimental stages (see 'Methods'). The shading that labels the 4 treatments corresponds to that used in subsequent figures. FSW: filtered seawater 
'phytoplankton only'), we concentrated $125 \mathrm{l}$ of water 25-fold by gentle reverse-gravity filtration through a $10 \mu \mathrm{m}$ mesh. The resulting $\sim 1$ of phytoplankton suspension was then diluted with $0.2 \mu \mathrm{m}$ filtered seawater (i.e. the $<10 \mu \mathrm{m}$ filtrate, which had been pressure filtered through a Whatman $0.2 \mu \mathrm{m}$ mixed cellulose ester membrane filter (142 mm diameter, Millipore) to a total volume of $25 \mathrm{l}$. This phytoplankton concentrate was not inoculated with bacteria as it was presumed to contain a sufficient concentration. The subsequent determination of bacterial abundance revealed a mean concentration at the start of the exposure of $1.36 \times 10^{6} \pm$ $4.34 \times 10^{4}$ cells ml ${ }^{-1}$ (mean $\pm \mathrm{SD}, \mathrm{n}=4$ ). The chlorophyll $a(\mathrm{chl} \mathrm{a})$ concentration $(>10 \mu \mathrm{m})$ at the start of the exposure was $3.01 \pm 0.31 \mathrm{\mu g} \mathrm{l}^{-1}$. In comparison, total in situ chl a was $1.81 \pm 0.15 \mu \mathrm{g} \mathrm{l}^{-1}$.

The exposure solution for the 'copepods only' and 'control' (without copepods and phytoplankton) treatments was obtained by inoculating 22.51 of $0.2 \mu \mathrm{m}$ filtered seawater with $2.5 \mathrm{l}$ of $3 \mu \mathrm{m}$ filtered (47 mm polycarbonate, Millipore) seawater. Bacterial abundance at the beginning of the exposure was $2.94 \times 10^{5} \pm 4.90 \times$ $10^{3}$ cells ml $\mathrm{m}^{-1}$ or $\sim 10 \%$ of the ambient bacterial concentration in the Bothnian Bay.

Start values of all environmental variables were determined from the exposure solutions (Table 1).

Copepods: Small copepods (mean length \pm SD: 0.57 $\pm 0.099 \mathrm{~mm}$, mainly Eurytemora affinis) were collected on the day of the experiment using a $90 \mu \mathrm{m}$ WP2 net with a closed cod end, from 10 to $0 \mathrm{~m}$ depth. Copepods were first gently filtered onto a $200 \mu \mathrm{m}$ submersed mesh to remove phytoplankton, and thereafter transferred to $0.2 \mu \mathrm{m}$ filtered seawater to allow them to empty their guts for $\sim 5 \mathrm{~h}$. Fecal pellets and detritus were pipetted away under a dissecting microscope. The volume was further diluted, and the pipetting was repeated until no new fecal pellets had been produced for $1 \mathrm{~h}$. Immediately prior to experiments, copepods were placed on a $50 \mu \mathrm{m}$ mesh and submersed in 5 successive baths of $0.2 \mu \mathrm{m}$ filtered seawater to remove bacteria. Portions of copepods were then transferred to

Table 1. Values of environmental variables in the exposure solutions at the beginning of the exposure $\left(t_{-1}\right)$. Chl a:

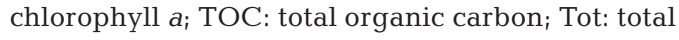

\begin{tabular}{|lcc|}
\hline Variable & + Phytoplankton & - Phytoplankton \\
\hline $\mathrm{Chl} \mathrm{a}\left(\mu \mathrm{g} \mathrm{l}^{-1}\right)$ & $3.01 \pm 0.31$ & Below detection \\
$\mathrm{TOC}\left(\mathrm{mg} \mathrm{l}^{-1}\right)$ & $4.80 \pm 0.14$ & $4.10 \pm 0.04$ \\
$\mathrm{PO}_{4}-\mathrm{P}\left(\mu \mathrm{g} \mathrm{l}^{-1}\right)$ & $2.25 \pm 0.09$ & $0.55 \pm 0.05$ \\
$\mathrm{Tot}-\mathrm{P}\left(\mu \mathrm{g} \mathrm{l}^{-1}\right)$ & $9.18 \pm 0.95$ & $3.15 \pm 0.03$ \\
$\mathrm{NH}_{4}-\mathrm{N}\left(\mu \mathrm{g} \mathrm{l}^{-1}\right)$ & $3.28 \pm 0.05$ & $2.82 \pm 0.16$ \\
$\mathrm{NO}_{2}-\mathrm{N}\left(\mu \mathrm{g} \mathrm{l}^{-1}\right)$ & $2.45 \pm 0.03$ & $2.28 \pm 0.02$ \\
$\mathrm{NO}_{3}-\mathrm{N}\left(\mu \mathrm{g} \mathrm{l}^{-1}\right)$ & $7.18 \pm 0.26$ & $8.42 \pm 0.19$ \\
Dissolved DNA $\left(\mathrm{ng} \mathrm{ml}^{-1}\right)$ & $1.07 \pm 0.08$ & $0.85 \pm 0.05$ \\
\hline
\end{tabular}

8 beakers, and the volume was adjusted with experimental solution to $40 \mathrm{ml}$. Copepods in each bottle were counted after the experiment. Average number of added copepods was 480 , corresponding to $\sim 218 \mathrm{l}^{-1}$ or $240 \mu \mathrm{g} \mathrm{C}^{-1}$, which is similar to the copepod C concentration used by Møller \& Nielsen (2001). Copepod concentration was estimated by applying an average biomass of $1.09 \mu \mathrm{g} \mathrm{C}$ copepod $^{-1}$, determined from length measurements of $>900$ copepods used here and a length-dry weight relationship from Burkill \& Kendall (1982) for E. affinis, assuming $45 \%$ carbon content (Hansen et al. 1997). Mean copepod concentration did not differ between the 2 treatments in which copepods were added ( $t$-test, $\mathrm{p}=0.17$ ). In comparison, in situ densities of mesozooplankters were $\sim 22 \mathrm{l}^{-1}$ at the time of sampling.

Experiment: The experimental design consisted of 4 treatments (i.e. 'copepods + phytoplankton', 'copepods only', 'phytoplankton only' and 'control'), each with 4 replicates (Fig. 1).

Immediately prior to the exposure, the 'exposure' solutions containing the bacteria were portioned out in 2.21 polyethylene bottles (Nalgene). The exposure stage started $\left(t_{-1}\right)$ when copepods were added and the bottles topped and sealed, and lasted for $\sim 1 \mathrm{~h}$ (Fig. 1). The short exposure was chosen to limit effects of fecal pellet production by the copepods in the containers. To minimize between-treatment variation in exposure time, we set up and sampled 1 bottle from each treatment followed by another from each treatment and so forth. There was no difference in mean exposure time between treatments (ANOVA, $\mathrm{p}=0.97$ ).

At the end of the exposure, reverse-gravity filtering of the water (10 $\mathrm{\mu m}$ mesh) was performed very gently, to minimize damage to phytoplankton cells and copepods. One litre of the $10 \mu \mathrm{m}$ filtrate from each 'exposure' bottle was further gravity filtered through a $3 \mu \mathrm{m}$ polycarbonate filter (47 mm, Millipore) into a clean bottle. This started the 'incubation', and this time was denoted as $t_{0}$. The filtrate was sampled every $6 \mathrm{~h}$ for bacterial abundance and production, and at $t_{0}$ and $t_{24}$ for DNA uptake and phosphatase activity, as well as for nutrients and D-DNA (details below). Sampling times were recorded individually for each container and variable.

Measured parameters. Nutrients: For each of nitrate/ nitrite, ammonia, ortho-phosphate and total phosphate, a $12 \mathrm{ml}$ sample was GF/F filtered into a $15 \mathrm{ml}$ polypropylene tube and frozen. Samples were analyzed with a Bran \& Luebbe TRAACS 800 autoanalyzer and standard seawater methods.

Total organic carbon (TOC): The $12 \mathrm{ml}$ samples were frozen in $15 \mathrm{ml}$ polypropylene tubes and analyzed using a Shimadzu TOC-5000 high temperature catalytic oxidation instrument. Samples were acidified 
and sparged prior to analysis. Calculation of carbon concentrations was performed with potassium hydrogen phthalate as the standard substance.

Dissolved DNA: Samples for D-DNA were fixed and analyzed as in Brum et al. (2004). Briefly, $100 \mathrm{ml}$ sample was $0.22 \mu \mathrm{m}$ filtered (Milipore No. SCGV U01 RE) and divided between two $50 \mathrm{ml}$ Falcon tubes. For estimating DNA recovery, Lambda DNA (Roche) was added to 1 tube (1 $\mathrm{ng} \mathrm{ml}^{-1}$, final). Thereafter, $1 \mathrm{M}$ autoclaved tetrasodium salt was added $(100 \mathrm{mM}$, final) to both tubes, which were then stored at $4^{\circ} \mathrm{C}$. Within $10 \mathrm{~d}$, DNA in triplicate $13 \mathrm{ml}$ aliquots from each tube was concentrated and washed with TE (10 mM Tris, 1 mM EDTA, pH 8) in Centricon Plus-20 filter units (Milipore No. UFC2 LGC). DNA concentration was measured in triplicate samples from each concentrate using SYBR Green I (Molecular Probes) and a FLUOstar plate reader (BMG). The detection limit was $0.05 \mathrm{ng}$ DNA ml${ }^{-1}$ seawater. Standard curves (Lambda Roche) were always linear $\left(\mathrm{R}^{2}>0.99\right)$. Final DNA concentrations were corrected for recovery, which ranged from 77 to $100 \%$.

Bacterial abundance: Samples were fixed with a paraformaldehyde-glutaraldehyde mix (1 and 0.05\%, final), frozen in liquid nitrogen and stored at $-80^{\circ} \mathrm{C}$. Bacteria were stained with SYTO 13 (Molecular Probes) and counted on a FACSCalibur flow cytometer (Becton Dickinson; Gasol \& del Giorgio 2000) using fluorescent beads (True counts, Becton Dickinson) as standards.

Bacterial production: Bacterial production was measured by $\left[{ }^{3} \mathrm{H}\right]$-thymidine incorporation (Fuhrman \& Azam 1982) as modified for microcentrifugation by Smith \& Azam (1992). Triplicate $1.7 \mathrm{ml}$ aliquots were incubated with [methyl- ${ }^{3} \mathrm{H}$ ]-thymidine $(25 \mathrm{nM}$, final, Amersham) in sterile $2.0 \mathrm{ml}$ capacity polypropylene tubes for ca. $1 \mathrm{~h}$ at in situ temperature. Samples with $5 \%$ trichloracetic acid added prior to the addition of isotope served as blanks. Thymidine incorporation was converted to carbon production using $1.4 \times 10^{18}$ cells $\mathrm{mol}^{-1}$ thymidine incorporated (average calculated from published Baltic Sea data, SE $=0.1 \times 10^{18} \mathrm{cells} \mathrm{mol}^{-1}$ thymidine, $n=73$; Helcom guidelines, www.helcom.fi/ groups/monas/CombineManual/AnnexesC/en_GB/an nex11/) and a carbon to cell ratio of $20 \mathrm{fg} \mathrm{C}$ bacterium $^{-1}$ (Lee \& Fuhrman 1987).

Alkaline phosphatase (AP) activity: Triplicate $4 \mathrm{ml}$ samples were incubated with the fluorogenic substrate methylumbelliferyl [MUF]-phosphate (Sigma) to determine potential ectoenzymatic alkaline phosphatase activity. Hydrolysis, seen as generation of fluorescence, was measured with a Turner TD-700 fluorometer using heat-killed samples as controls. The fluorometer was calibrated with standard solutions of MUF (Sigma), and potential activities at $100 \mu \mathrm{M}$ substrate concentration were measured.
DNA uptake: Lambda DNA (1 $\mu \mathrm{g}$, Roche) was labeled using ${ }^{32} \mathrm{P}$-cytidine and a nick translation kit (N5000) following the manufacturer's instructions (GE Healthcare). The product had a specific activity of $\sim 2.5 \times 10^{8} \mathrm{cpm} \mu \mathrm{g} \mathrm{DNA}{ }^{-1}$ and, according to the manufacturer, a length $>500 \mathrm{bp}$. Labeled DNA was added to triplicate $1 \mathrm{ml}$ samples and 2 control samples in $2 \mathrm{ml}$ Eppendorf tubes (3 ng DNA ml ${ }^{-1}$, final). Control samples were cooled in ice water prior to the addition of labeled DNA. Samples were incubated at in situ temperature $\pm 1^{\circ} \mathrm{C}$ for $\sim 4 \mathrm{~h}$, while controls were incubated in ice water. Incubation was terminated by filtration onto $0.2 \mu \mathrm{m}$ mixed cellulose ester filters (Advantec). These were then thoroughly washed with ice-cold $0.9 \% \mathrm{NaCl}$, dissolved in $1 \mathrm{ml}$ ethyl acetate, and radio assayed after adding $9 \mathrm{ml}$ Ultima Gold liquid scintillation cocktail (Perkin Elmer).

Data treatment and statistics. Cell-specific activity rates at $t_{0}$ and $t_{24}$ were obtained by dividing the measured community response (i.e. activity per volume) with the cell concentration for each individual bottle at $t_{0}$ and $t_{24}$. Statistical analyses were conducted in SPSS 14.0 or in R. Because the setup required the use of 2 different exposure solutions (i.e. \pm phytoplankton) (cf. Fig. 1), most variables differed systematically between treatments at the beginning of the incubation (i.e. at $t_{0}$ ) (Table 1). To obtain comparable data for the 4 treatments, we therefore calculated, for each variable and individual bottle, the difference during the incubation normalized to the start concentration (i.e. $\left[x_{t_{24}}-x_{t_{0}}\right] / x_{t_{0}}$ ) before further statistical analysis. Unless otherwise noted, data were analyzed with a 1-way ANOVA, with treatment as a fix factor, after testing for homoscedasity with Levene's test. Subsequent to significant ANOVAs, any differences between treatments were detected with LSD (least significant differences) post hoc tests.

While exposure time did not differ between treatments (see 'Methods-Experimental setup'), the within-treatment variation in exposure time may be reflected in larger variations in measured parameters, especially in the 'copepods + phytoplankton' treatment (cf. Figs. $5 \& 6$ ). When the equal variance assumptions of ANOVA were not fulfilled, non-parametric methods were used to test for a general treatment effect.

Additional Spearman's ranked correlation analyses (1-tailed) using all bottles (i.e. $\mathrm{n}=16$, or $\mathrm{n}=8$ for DNA uptake) were conducted to further test observed similarities between activity measures and/or environmental variables. In addition, multivariate methods were used to analyze the treatment effects on cell-specific AP activity and growth in junction. We applied Hotelling's $T$-squared test with a pooled variancecovariance matrix to test for differences between treatments. The p-values were adjusted with Holm's method for multiple comparisons. 
We restricted our quantitative analysis to the actual incubation data, where only particles $<3 \mu \mathrm{m}$ are present (i.e. $t_{0}$ to $t_{24}$ ). The inclusion of a copepods-only treatment enabled the differentiation of feeding-related activities (in the 'copepods + phytoplankton' treatment) and other activities (in the 'copepods only' treatment), as copepods do not feed in absence of sufficiently large food (Berggreen et al. 1988).

\section{RESULTS}

The following results are divided into measures of alterations in the environment due to the experimental treatment and measures of bacterial activity responses due to those environmental alterations.

\section{Alteration of bacterial growth environment}

Concentrations of nutrients and D-DNA are shown in Fig. 2. The most notable changes during the incubation $\left(t_{0}\right.$ to $\left.t_{24}\right)$ were the net decreases in $\mathrm{PO}_{4}-\mathrm{P}$ and Tot-P in all of the treatments (Fig. 3A). This suggests that net releases of $\mathrm{P}$ compounds from copepods and phytoplankton are masked by a high bacterial uptake of $\mathrm{P}$ (see below). The relative net decrease in $\mathrm{PO}_{4}-\mathrm{P}$ and Tot-P was affected by treatment, with the strongest decrease in the 'copepods + phytoplankton' treatment, which differed significantly from the other treatments, including the 'phytoplankton only' treatment for both $\mathrm{PO}_{4}-\mathrm{P}$ and Tot-P (Fig. 3A). This treatment also showed the largest bacterial activity and DNA uptake (see 'Bacterial abundance and activity' below). $\mathrm{NH}_{4}$ concentrations responded similarly, although the treatment effect was not quite significant (Kruskal-Wallis, $p=0.057$ ) (Fig. 3A). However, the change in $\mathrm{NH}_{4}$ was correlated with the changes in $\mathrm{PO}_{4}-\mathrm{P}$, Tot-P and D-DNA (Table 2).

During incubation, the level of D-DNA decreased significantly more in the 'copepods + phytoplankton' treatment than in the 'phytoplankton only' treatment and other treatments (Fig. 3B,C). Apparently, any released DNA was rapidly used (cf. DNA uptake), especially in the 'copepods + phytoplankton' treatment. The pattern observed for D-DNA fits well with the general picture of highest change in bacterial activity measures in the treatments with 'copepods + phytoplankton', and the lowest in the 'control' treatment (see Figs. 5 \& 6).
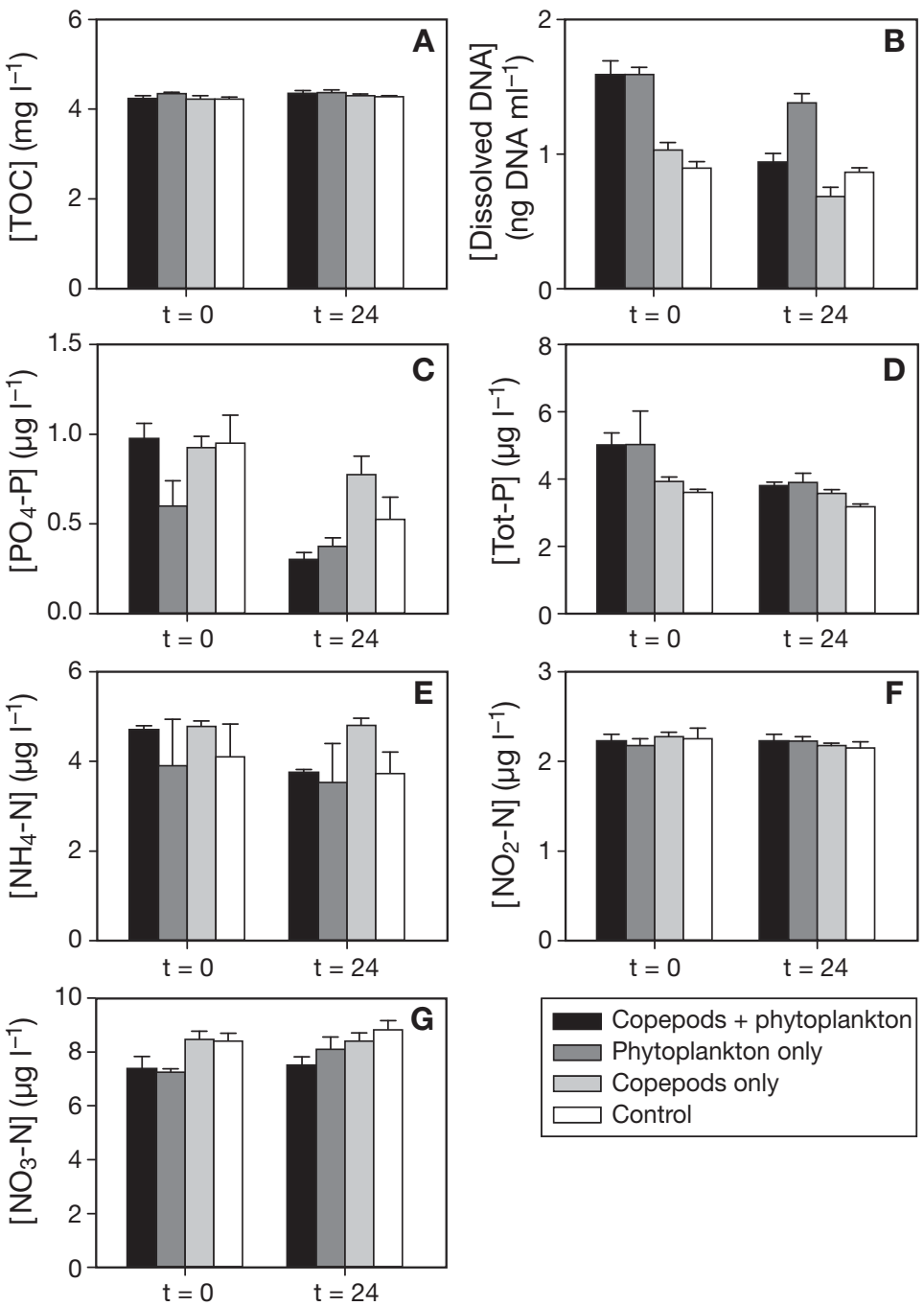

Fig. 2. Environmental variables at the start $\left(t_{0}\right)$ and end $\left(t_{24}\right)$ of the incubation (cf. Fig. 1). Data are means $( \pm \mathrm{SE})$ of 4 replicates per treatment: (A) TOC (total organic carbon), (B) dissolved DNA, (C) $\mathrm{PO}_{4}-\mathrm{P}$, (D) Tot-P, (E) $\mathrm{NH}_{4}-\mathrm{N}$, (F) $\mathrm{NO}_{2}-\mathrm{N}$ and (G) $\mathrm{NO}_{3}-\mathrm{N}$

\section{Bacterial abundance and activity}

Bacterial abundance generally increased by $<40 \%$ between the start and stop of the incubations, while there were no significant effects of treatments (Fig. 4). The effects on microbial activity (Figs. $5 \& 6$ ) were thus not reflected in bacterial abundance when measured at our time scale and temperature. Activities are reported as per unit volume and cell-specific values.

Treatment had a significant effect on bacterial production, which generally increased with time in all treatments, and most so in the 'copepods + phytoplankton' treatment (Fig. 5A). Treatment also had a significant effect on cell-specific bacterial production (Fig. 6A). Specific bacterial production increased most 

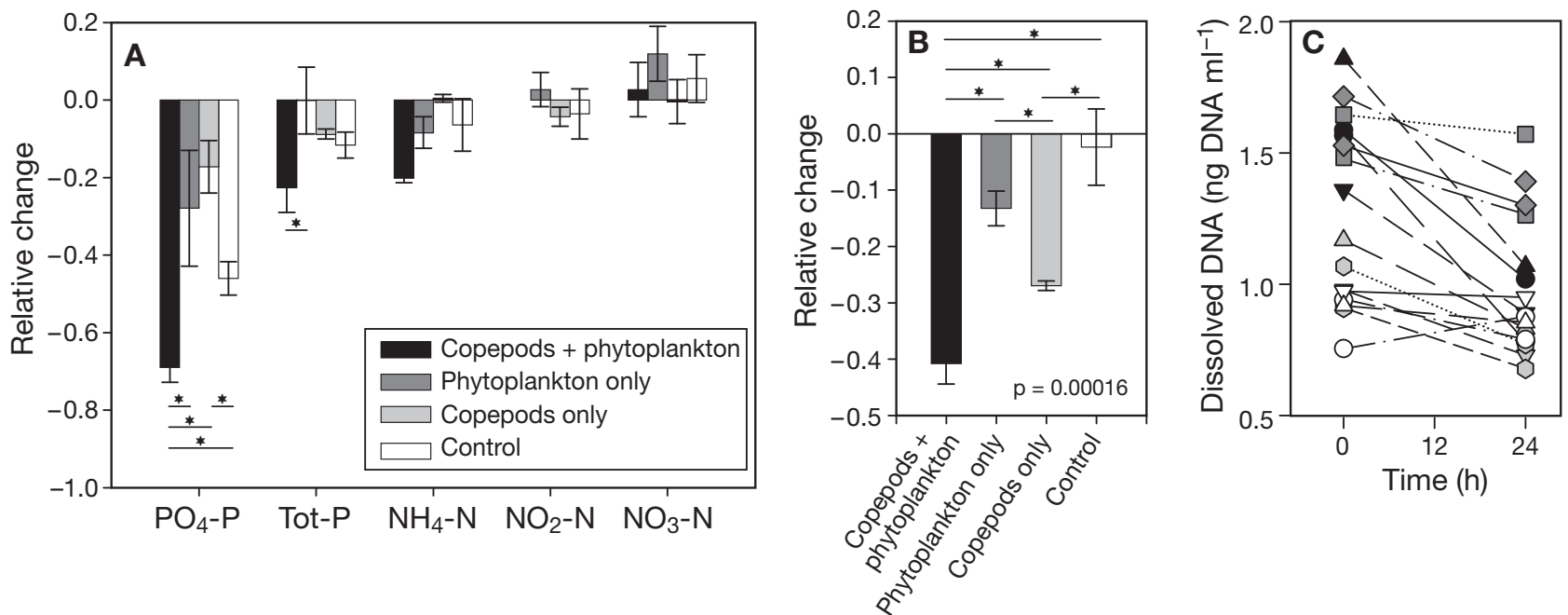

Fig. 3. Relative changes in (A) nutrient concentrations and $(B, C)$ dissolved DNA during the experiment. Data are differences normalized to start concentrations, reported as means $( \pm \mathrm{SE})\left(\right.$ see 'Methods'). ${ }^{*}$ Significant differences $(\mathrm{p}<0.05)$ indicated by post hoc LSD tests. (A) Changes in $\mathrm{PO}_{4}$-P (ANOVA, $\mathrm{p}=0.006$ ) and Tot-P (ANOVA, $\mathrm{p}=0.039$ ) differed significantly between treatments, while there were no significant effects on the other nutrients ( $p>0.05)$. (B) There was a significant treatment effect on dissolved DNA concentrations (ANOVA, $\mathrm{p}=0.00016$ ). (C) Raw data. Symbol types represent individual bottles. Shading denotes treatments in all panels

Table 2. Spearman's ranked correlations between relative difference in bacterial activity measures and the environmental data in the individual bottles. Data are correlation coefficients with $p$-values in parentheses. ${ }^{*} p<0.05 ;{ }^{* *} p<0.005 ;$ NA: nonapplicable or nonsense correlations; Bact.: bacterial; prod.: production; spec.: specific; AP: alkaline phosphatase; Tot: total; D-DNA: dissolved DNA

\begin{tabular}{|c|c|c|c|c|c|c|c|c|c|c|c|}
\hline & $\begin{array}{l}\text { Bact. } \\
\text { prod. }\end{array}$ & $\begin{array}{l}\text { Cell } \\
\text { spec. } \\
\text { bact. } \\
\text { prod. }\end{array}$ & $\begin{array}{c}\text { AP } \\
\text { activity }\end{array}$ & $\begin{array}{c}\text { Cell } \\
\text { spec. } \\
\text { AP } \\
\text { activity }\end{array}$ & $\begin{array}{l}\text { DNA } \\
\text { uptake }\end{array}$ & $\begin{array}{c}\text { Cell } \\
\text { spec. } \\
\text { DNA } \\
\text { uptake }\end{array}$ & $\mathrm{PO}_{4}-\mathrm{P}$ & Tot-P & $\mathrm{NH}_{4}$ & $\mathrm{NO}_{2}-\mathrm{N}$ & $\mathrm{NO}_{3}-\mathrm{N}$ \\
\hline $\begin{array}{l}\text { Cell spec. } \\
\text { bact. prod. }\end{array}$ & NA & & & & & & & & & & \\
\hline AP activity & $\begin{array}{c}0.458^{*} \\
(0.037)\end{array}$ & NA & & & & & & & & & \\
\hline $\begin{array}{l}\text { Cell spec. } \\
\text { AP activity }\end{array}$ & NA & $\begin{array}{c}0.399 \\
(0.063)\end{array}$ & NA & & & & & & & & \\
\hline DNA uptake & $\begin{array}{l}-0.119 \\
(0.389)\end{array}$ & NA & $\begin{array}{c}0.623^{*} \\
(0.050)\end{array}$ & NA & & & & & & & \\
\hline $\begin{array}{l}\text { Cell spec. } \\
\text { DNA uptake }\end{array}$ & NA & $\begin{array}{l}-0.119 \\
(0.389)\end{array}$ & NA & $\begin{array}{c}0.595 \\
(0.060)\end{array}$ & NA & & & & & & \\
\hline $\mathrm{PO}_{4}-\mathrm{P}$ & $\begin{array}{l}-0.376 \\
(0.076)\end{array}$ & $\begin{array}{l}-0.419 \\
(0.053)\end{array}$ & $\begin{array}{l}-0.388 \\
(0.069)\end{array}$ & $\begin{array}{l}-0.482^{*} \\
(0.029)\end{array}$ & $\begin{array}{c}-0.13 \\
(0.378)\end{array}$ & $\begin{array}{l}-0.132 \\
(0.378)\end{array}$ & & & & & \\
\hline Tot-P & $\begin{array}{l}-0.122 \\
(0.326)\end{array}$ & $\begin{array}{l}-0.202 \\
(0.226)\end{array}$ & $\begin{array}{l}-0.127 \\
(0.319)\end{array}$ & $\begin{array}{l}-0.232 \\
(0.194)\end{array}$ & $\begin{array}{l}-0.286 \\
(0.246)\end{array}$ & $\begin{array}{l}-0.286 \\
(0.246)\end{array}$ & $\begin{array}{c}0.382 \\
(0.072)\end{array}$ & & & & \\
\hline $\mathrm{NH}_{4}$ & $\begin{array}{l}-0.333 \\
(0.104)\end{array}$ & $\begin{array}{l}-0.368 \\
(0.080)\end{array}$ & $\begin{array}{l}-0.526^{*} \\
(0.018)\end{array}$ & $\begin{array}{l}-0.645^{* *} \\
(0.004)\end{array}$ & $\begin{array}{l}-0.265 \\
(0.263)\end{array}$ & $\begin{array}{l}-0.265 \\
(0.263)\end{array}$ & $\begin{array}{l}0.662^{* *} \\
(0.003)\end{array}$ & $\begin{array}{r}0.532^{*} \\
(0.017)\end{array}$ & & & \\
\hline $\mathrm{NO}_{2}-\mathrm{N}$ & $\begin{array}{c}0.433^{*} \\
(0.047)\end{array}$ & $\begin{array}{c}0.354 \\
(0.090)\end{array}$ & $\begin{array}{c}0.344 \\
(0.096)\end{array}$ & $\begin{array}{c}0.083 \\
(0.380)\end{array}$ & $\begin{array}{l}0.000 \\
(0.50)\end{array}$ & $\begin{array}{l}0.000 \\
(0.50)\end{array}$ & $\begin{array}{c}0.102 \\
(0.353)\end{array}$ & $\begin{array}{c}0.193 \\
(0.237)\end{array}$ & $\begin{array}{c}0.216 \\
(0.211)\end{array}$ & & \\
\hline $\mathrm{NO}_{3}-\mathrm{N}$ & $\begin{array}{c}0.285 \\
(0.142)\end{array}$ & $\begin{array}{c}0.304 \\
(0.126)\end{array}$ & $\begin{array}{c}0.111 \\
(0.341)\end{array}$ & $\begin{array}{l}-0.102 \\
(0.354)\end{array}$ & $\begin{array}{c}0.048 \\
(0.455)\end{array}$ & $\begin{array}{c}0.048 \\
(0.455)\end{array}$ & $\begin{array}{c}0.157 \\
(0.280)\end{array}$ & $\begin{array}{c}0.109 \\
(0.344)\end{array}$ & $\begin{array}{c}0.402 \\
(0.061)\end{array}$ & $\begin{array}{r}0.513^{*} \\
(0.021)\end{array}$ & \\
\hline D-DNA & $\begin{array}{l}-0.400 \\
(0.062)\end{array}$ & $\begin{array}{l}-0.325 \\
(0.109)\end{array}$ & $\begin{array}{l}-0.706^{* *} \\
(0.001)\end{array}$ & $\begin{array}{l}-0.636^{* *} \\
(0.004)\end{array}$ & $\begin{array}{l}-0.419 \\
(0.151)\end{array}$ & $\begin{array}{l}-0.419 \\
(0.151)\end{array}$ & $\begin{array}{c}0.254 \\
(0.172)\end{array}$ & $\begin{array}{r}0.552^{*} \\
(0.013)\end{array}$ & $\begin{array}{c}0.472^{*} \\
(0.032)\end{array}$ & $\begin{array}{l}-0.251 \\
(0.175)\end{array}$ & $\begin{array}{l}-0.034 \\
(0.450)\end{array}$ \\
\hline
\end{tabular}



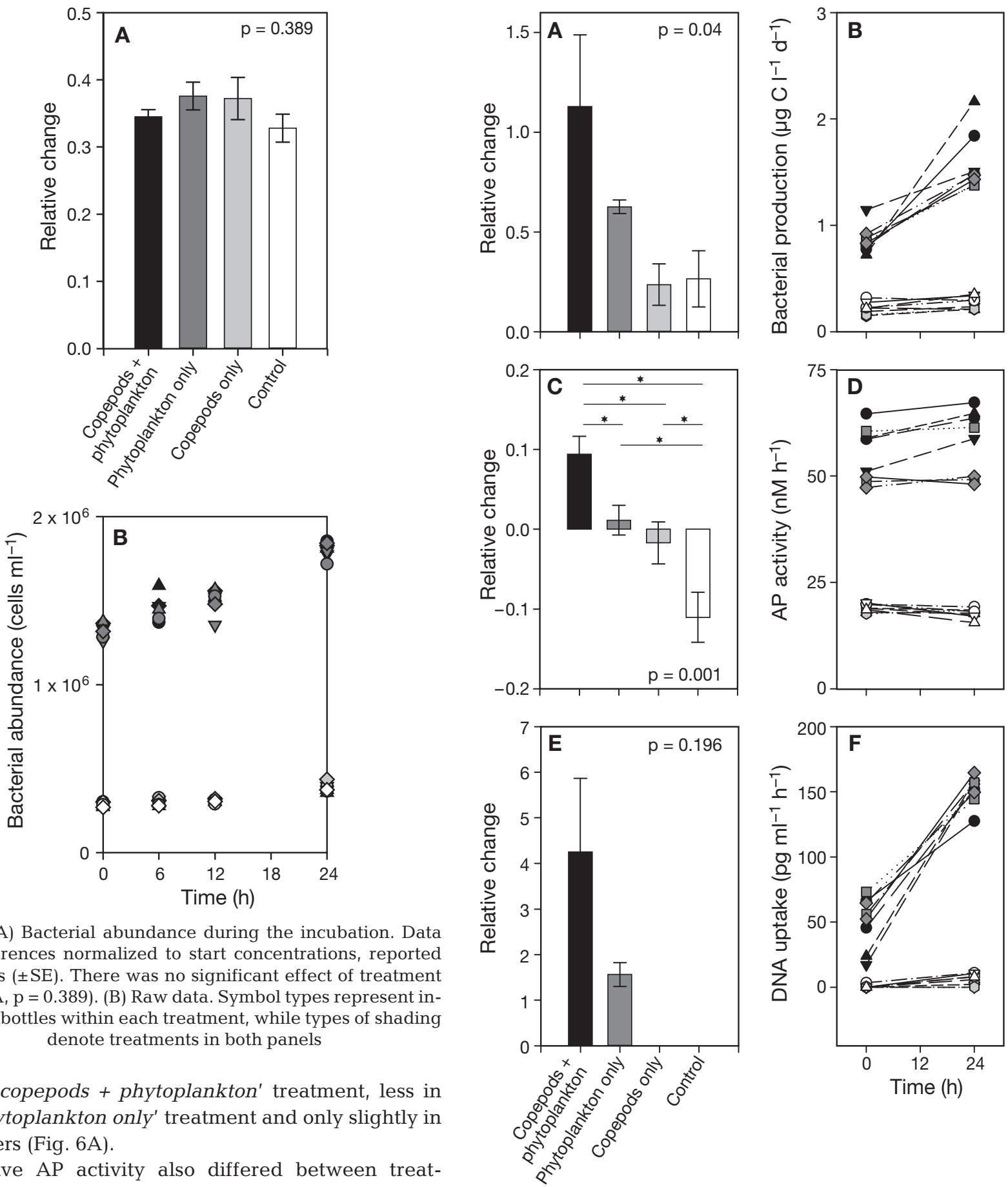

Fig. 5. Bacterial activities. $(\mathrm{A}, \mathrm{B})$ Bacterial production, $(\mathrm{C}, \mathrm{D})$ alkaline phosphatase (AP) activity and (E,F) DNA uptake. $(\mathrm{A}, \mathrm{C}, \mathrm{E})$ Differences normalized to start values, reported as means $( \pm \mathrm{SE}$ ) (see 'Methods'). Panels B, D and F are raw data for the individual bottles. Symbol types represent individual bottles within each treatment. Treatment had a significant effect on bacterial production (Kruskal-Wallis, $\mathrm{p}=0.04$ ) and AP activity (ANOVA, $p=0.001$ ), while it was not significant for DNA uptake rate ( $t$-test, non-equal variance, $\mathrm{p}=0.196)$.

${ }^{*}$ Significant differences $(p<0.05)$ indicated by post hoc LSD tests. Types of shading denote treatments in all panels 

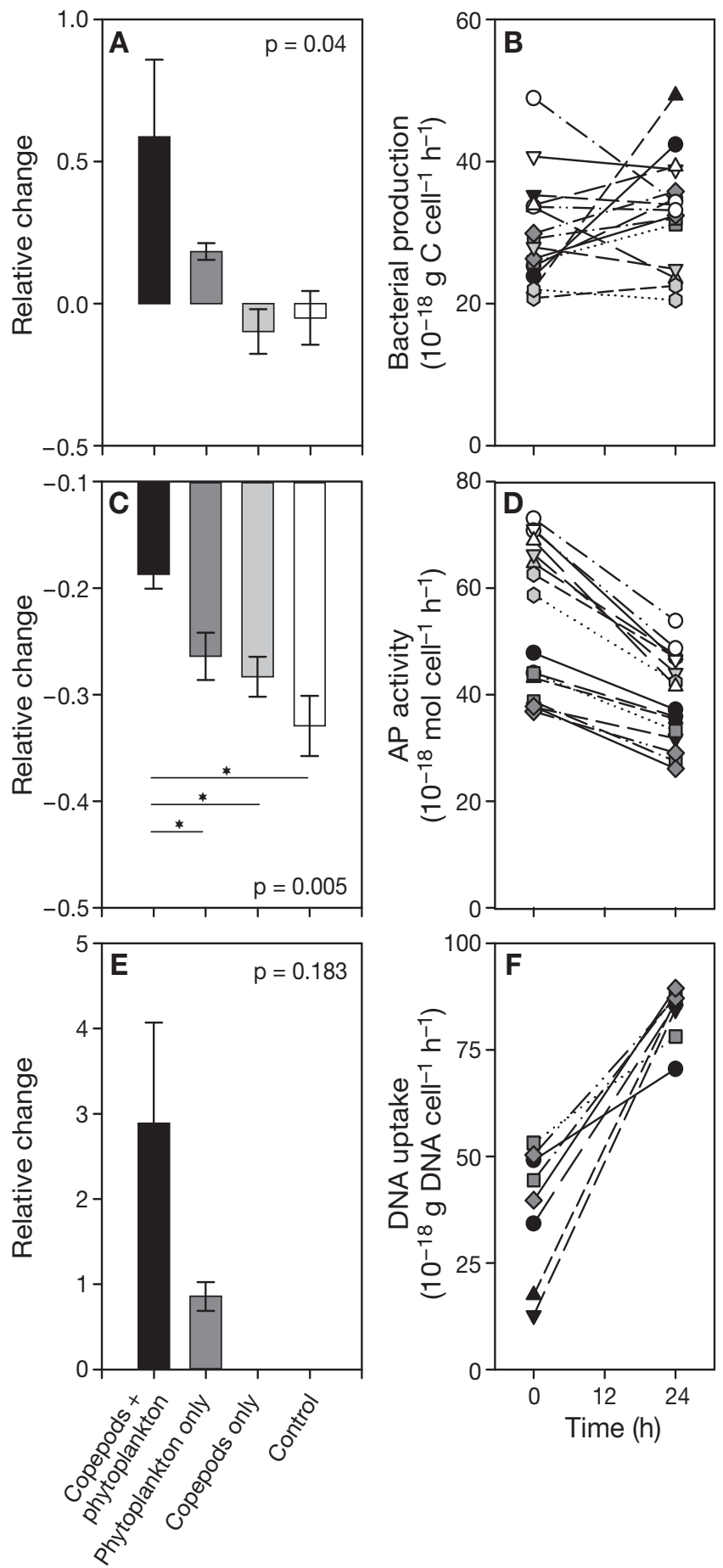

Fig. 6. Cell-specific bacterial activities. $(\mathrm{A}, \mathrm{B})$ Bacterial production, $(\mathrm{C}, \mathrm{D})$ alkaline phosphatase (AP) activity and $(\mathrm{E}, \mathrm{F})$ DNA uptake. (A,C,E) Differences normalized to start values, reported as means $( \pm \mathrm{SE}), \mathrm{n}=4$. Treatment had a significant effect on bacterial production (Kruskal-Wallis, $p=0.04$ ) and AP activity (ANOVA, $p=0.005$ ), while it was not significant for DNA uptake rate ( $t$-test, non-equal variance assumed, $\mathrm{p}=$ $0.183)$. ${ }^{*}$ Significant differences $(p<0.05)$ indicated by post hoc LSD tests. $(B, D, F)$ Symbol types represent individual bottles within each treatment. Types of shading denote treatments in all panels phytoplankton was offered (Fig. 5F). Therefore, comparisons are only possible between the 'copepods + phytoplankton' and 'phytoplankton only' treatments (Figs. 5E \& 6E). Because of the non-equal variances between treatments, the apparently greater changes in DNA uptake rates in the 'copepods + phytoplankton' treatment were not significantly different from those in the 'phytoplankton only' treatment, for either per volume or cell-specific DNA uptake rates (Figs. 5E \& 6E). The higher variance in the 'copepods + phytoplankton' treatment was partly explained by lower uptake at $t_{0}$ in some of these bottles (Figs. 5E,F \& 6E,F). However, because the increase was computed for individual bottles prior to averaging, this does not challenge the overall pattern.

Additional correlation analyses indicated that the different bacterial activity measures responded similarly to the treatments. Changes in DNA uptake were positively correlated to changes in AP activity (Table 2). Similarly, AP activity was correlated to production (Table 2). A scatter plot of the relative changes in cell-specific AP activity versus production (not shown, data in Fig. 6) revealed that the points for 'copepods + phytoplankton' are well separated from the others by a straight line. Therefore, a multivariate test (Hotelling's $T$-squared test) is appropriate to discriminate between the treatments, while considering both AP activity and production in junction. Because the patterns of points were very similar within all treatments, we were able to use all treatments in estimating the variance-covariance matrix, and thereby strengthen the conclusion. This analysis broadcasts the effect of copepod grazing on bacterial activities as indicated by the significant differences between the 'copepods + phytoplankton' and 'phytoplankton only' treatments $(\mathrm{T} 2=14.28, \mathrm{p}=0.0061$, Holm's corrected $\mathrm{p}=0.024)$.

Changes in background parameters were also correlated with activities and with each other. For example, changes in D-DNA were negatively correlated with changes in AP activity, and changes in $\mathrm{PO}_{4}-\mathrm{P}$ and $\mathrm{NH}_{4}$ were both correlated with cell-specific AP activity changes (Table 2).

In summary, the consistent patterns in bacterial activity measures in the different treatments (Figs. 5 \& 6) suggest that copepod feeding activity stimulates bacterial activity measured as AP activity, DNA uptake and production.

\section{DISCUSSION}

While bacterial utilization of DOC produced by zooplankton sloppy feeding has been demonstrated repeatedly (e.g. Møller \& Nielsen 2001), our (albeit limited) dataset suggests that zooplankton grazing also 
leads to increased AP activity, production and uptake of D-DNA by bacteria (Figs. 5 \& 6). Particularly, in P-limited systems like the Bothnian Bay, microbial utilization of DOP released by zooplankton sloppy feeding may represent an important pathway in pelagic P dynamics.

\section{$P$ and bacterial activities}

Along with endo- and exonucleases and 5'-nucleotidase, AP activity liberates orthophosphate from DNA molecules (Siuda et al. 1998). Both bacterio- and phytoplankton produce AP enzyme (Ammerman \& Azam 1985). AP activity is repressed by inorganic $P$ (Perry 1972), and it is usually highest in P-depleted environments (Chróst 1991). In our P-limited system, copepod grazing stimulated bacterial production and total AP activity (Fig. 5), while cell-specific AP activity decreased during the experiment (Fig. 6). We speculate that the generation of accessible $C$, when compared to the background non-accessible riverine $\mathrm{C}$, and D-DNA triggered overall bacterial activity, while the per cell synthesis of AP was gradually repressed by increasing intracellular levels of P (Chróst 1991). Also, levels of available P decreased during the experiment, suggesting that $\mathrm{P}$ was readily taken up by the bacteria (Fig. 3).

AP activity, that is the cleavage of an artificial substrate, provides no information about bacterial uptake of cleavage products. To roughly estimate if uptake of organic P was quantitatively important for bacterial growth, we measured bacterial uptake of radio-labeled DNA directly. DNA uptake increased $\sim 3$-fold during the $24 \mathrm{~h}$ duration of the incubation in the treatment with zooplankton grazing to a final level of $\sim 3.6 \mu \mathrm{g}$ DNA $\mathrm{l}^{-1} \mathrm{~d}^{-1}$ (Figs. 5E,F \& 6E,F). This level is within the range in enclosures in a nutrient-rich fjord, as measured by Jørgensen \& Jacobsen (1996) (0.96 to $21.6 \mu \mathrm{g}$ DNA $\mathrm{l}^{-1} \mathrm{~d}^{-1}$, measured using ${ }^{3} \mathrm{H}$-labeled PCR products).

\section{Turnover of D-DNA}

The turnover time of D-DNA was estimated to approximately 6 to $40 \mathrm{~h}$ (calculated as D-DNA concentration divided by bacterial uptake assuming steadystate conditions). This is shorter than in one nutrientrich estuary (47 \pm 68 h; Jørgensen \& Jacobsen 1996), but not shorter than in another eutrophic estuary (6.5 hi Paul et al. 1987) or in nutrient-rich and -poor limnetic systems ( 10 h; Paul et al. 1989). The short turnover time pinpoints DNA as a high-quality resource capable of supporting microbial metabolism (Paul et al. 1987).
Hydrolysis and uptake of D-DNA is higher in P-limited systems (the northern Baltic Sea and the Adriatic Sea) than in non-P-limited waters (Turk et al. 1992) and may therefore contribute relatively more to the bacterial P demand. For instance, DNA uptake covered 17 to $46 \%$ of the bacterial $\mathrm{P}$ demand in nonsupplemented estuarine water, while the addition of $\mathrm{P}$ reduced this to 2-9\% (Jørgensen \& Jacobsen 1996). To estimate the contribution of DNA bound P to the bacterial $\mathrm{P}$ demand in our system, we divided bacterial production rates (assuming a C:P ratio of 37:1; Tezuka 1990) with the DNA uptake rate (assuming that DNA contains 9.7\% P; Brum 2005). This crude calculation suggests that DNA uptake accounted for the bacterial $\mathrm{P}$ requirement at $t_{0}$ and exceeded this 2.5 -fold at $t_{24}$. These values are higher than those of Jørgensen \& Jacobsen (1996, see above, this subsection). Other comparative data from natural systems are scarce. However, it has been shown that the intracellular $\mathrm{P}$ content per dry weight of cultivated marine bacteria may vary up to 3-fold (Sudo et al. 1997). Our DNA uptake measurements suggest a luxury consumption of $\mathrm{P}$ that generated a changed cell stoichiometry without a corresponding change in cell abundance. Storage of inorganic polyphosphate (poly-P), a linear polymer of orthophosphate residues, is common in bacteria (e.g. Kornberg 1995, Sudo et al. 1997) and phytoplankton (Selig et al. 2002) and may act as an intracellular reservoir of energy and phosphate. Such storage may serve as a buffer against stress and ensure a stable level of inorganic P when hydrolyzed by intracellular exopolyphosphatases (Kornberg 1995). We speculate that the bacteria in our experiment, through $\mathrm{P}$ luxury consumption, generated poly-P, which may then have been utilized during subsequent periods of nutritional stress (low inorganic P conditions), similar to observations in phytoplankton (Selig et al. 2002).

The contribution of DNA uptake to the bacterial P demand may be at the higher end. Firstly, our estimate of bacterial production could be low due to conversion factors (Bjørnsen \& Riemann 1988) and the inability of some bacterial species to take up thymidine (Delille 2000). Secondly, the tracer used here (nick-translated lambda DNA) may be unrepresentative of natural DDNA, and DNA uptake rate might therefore be overestimated. Jørgensen \& Jacobsen (1996) found that small DNA pieces (100 bp) were taken up much faster than larger pieces (250 to $569 \mathrm{bp}$ ). They suggested that uptake of larger pieces requires activation of an enzyme apparatus (Jørgensen \& Jacobsen 1996), which could explain their findings of quite similar uptake rates of 250 and $569 \mathrm{bp}$ fragments. Both the fragments used here ( $>500 \mathrm{bp}$ ) and natural D-DNA in oligotrophic environments $(0.24$ to $14.27 \mathrm{~kb}$; DeFlaun et al. 1987) presumably require specific transport sys- 
tems or extracellular nucleases. We therefore do not believe that the potential overestimate is significant; still, this potential bias should be kept in mind.

\section{DOC and DOP release during sloppy feeding}

The nature of DOP release in comparison with DOC release during sloppy feeding is not known, but expectedly differs somewhat for several reasons. Firstly, stoichiometry varies between cell parts, and these may be differently released during sloppy feeding. Secondly, the nucleic acid content per cell volume is not constant, such that the DOP:DOC ratio differs for matter released from differently sized cells (Shuter et al. 1983). Nevertheless, as a first proxy, one may expect that release of DOP during sloppy feeding depends on some of the same factors as release of DOC, e.g. prey size, predator size and feeding strategy.

Møller (2007) quantified the fraction of the cleared food, which is lost as DOC $(Q)$ through sloppy feeding as a function of predator to prey size ratios for 3 small copepod species and arrived at the general equation:

$Q=0.368-0.009 \times \frac{E \mathrm{SD}_{\text {copepod }}}{E \mathrm{SD}_{\text {prey }}}$ for copepod-prey size ratios $>3$ and $<33$, where ESD is the equivalent spherical diameter (mm). This estimate is conservative compared to previous ones (e.g. Roy et al. 1989, Møller \& Nielsen 2001, Møller 2005). Although the fitted model ignores potential differences in DOM release due to, for example, prey shape, it still represents a useful proxy of sloppy

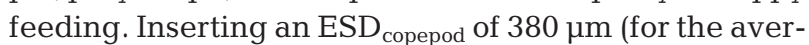
age copepod used in our experiments, calculated as in Hansen et al. 1997) implies that prey need to exceed $9.2 \mu \mathrm{m}$ for a contribution through sloppy feeding. In our experiments, the minimum prey size was $10 \mu \mathrm{m}$ (see 'Methods'), and chain-forming diatoms (e.g. Thalassiossira baltica, Chaetoceros wighamii, Skeletonema costatum) of varying size dominated at the time of water collection (the Swedish Marine Monitoring Program, Swedish Environmental Protection Agency). For example, the common diatom $T$. baltica (30 to $70 \mu \mathrm{m}$ ) yields a $Q$ of 25 to $32 \%$. In the Bothnian Bay, large diatoms normally dominate the spring bloom, phytoplankton >10 $\mu \mathrm{m}$ dominate during early summer, while smaller nanoflagellates dominate the autumn peak (Kuparinen et al. 1996).

Despite the potential differences between DOC and DOP release during sloppy feeding, the crude calculations suggest that the role of zooplankton as P generators shifts with seasonal changes in phytoplankton and zooplankton community composition and abundance, being most important in spring and summer. Our study was not designed to estimate the rates of release per se (e.g. concentrations of copepods and phytoplankton, respectively, were about 10 - and 2-fold higher than in situ), but rather to test for potential effects of sloppy feeding on P-related bacterial activities. Additional studies are required to quantify the rates of $\mathrm{P}$ generation by feeding zooplankters as a function of e.g. different size types and concentrations of prey, as well as to elucidate the relative importance of sloppy feeding as a P source in this and other P-limited systems.

\section{Conclusions}

Despite the limitations of our dataset, and although reservations apply when extrapolating experiments to nature, our findings of elevated microbial growth, phosphatase activity and luxury consumption of $\mathrm{P}$ in response to copepod grazing are noteworthy. We speculate that during times of elevated copepod grazing, bacterioplankton in the P-limited Bothnian Bay store $\mathrm{P}$ as intracellular poly-phosphate. This may then be gradually translated into biomass, prolong subsequent bacterioplankton growth, and extend utilization of DOM low in $\mathrm{P}$ content, such as the riverine DOM (Kuparinen et al. 1996), which is particularly prominent in this northern Baltic region.

Acknowledgements. We thank Calle Stangenberg and the rest of the staff for helping us find our way at the Umeå Marine Sciences Centre. We thank Jonas Wester and Mikael Molin for help in the field, and Johan Wikner for providing the thymidine conversion factor. Comments from Karen Wilson, Peter Tiselius and 3 anonymous reviewers on previous drafts improved this paper. This study was supported by a guest research grant from Umeå Marine Sciences Centre to J.T. and L.R., and a grant from FORMAS (2006-1054) to J.T.

\section{LITERATURE CITED}

Alonso MC, Rodriguez V, Rodriguez J, Borrego JJ (2000) Role of ciliates, flagellates and bacteriophages on the mortality of marine bacteria and on dissolved-DNA concentration in laboratory experimental systems. J Exp Mar Biol Ecol 244: $239-252$

Ammerman JW, Azam F (1985) Bacterial 5'-nucleotidase in aquatic ecosystems: a novel mechanism of phosphorus regeneration. Science 227:1338-1340

Berggreen U, Hansen B, Kiørboe T (1988) Food size spectra, ingestion and growth of the copepod Acartia tonsa during development: implications for determination of copepod production. Mar Biol 99:341-352

Björkman KM, Karl DM (2003) Bioavailability of dissolved organic phosphorus in the euphotic zone at Station ALOHA, North Pacific Subtropical Gyre. Limnol Oceanogr 48: 1049-1057

Bjørnsen PK, Riemann B (1988) Towards a quantitative stage in the study of microbial processes in pelagic carbon flows. Arch Hydrobiol 31:185-193

Brum JR (2005) Concentration, production and turnover of viruses and dissolved DNA pools at Stn ALOHA, North Pacific Subtropical Gyre. Aquat Microb Ecol 41:103-113 
Brum JR, Steward GF, Karl DM (2004) A novel method for the measurement of dissolved deoxyribonucleic acid in seawater. Limnol Oceanogr Methods 2:248-255

Burkill PH, Kendall TF (1982) Production of the copepod Eurytemora affinis in the Bristol Channel. Mar Ecol Prog Ser $7: 21-31$

Chróst RJ (1991) Environmental control of the synthesis and activity of aquatic microbial ectoenzymes. In: Chróst RJ (ed) Microbial enzymes in aquatic environments. Springer, New York

DeFlaun MF, Paul JH, Jeffrey WH (1987) Distribution and molecular weight of dissolved DNA in subtropical estuarine and oceanic environments. Mar Ecol Prog Ser 38: $65-73$

Delille D (2000) Species-specific variability in thymidine uptake rates in subantarctic marine bacterial isolates. Vie Milieu 50:79-86

Fuhrman JA, Azam F (1982) Thymidine incorporation as a measure of heterotrophic bacterioplankton production in marine surface waters: evaluation and field results. Mar Biol 66:109-120

Gasol JM, del Giorgio PA (2000) Using flow cytometry for counting natural planktonic bacteria and understanding the structure of planktonic bacterial communities. Sci Mar 64:197-224

Hansen PJ, Bjørnsen PK, Hansen BW (1997) Zooplankton grazing and growth: scaling within the 2-2000 $\mu \mathrm{m}$ body size range. Limnol Oceanogr 42:687-704

> Hansson LJ, Norrman B (1995) Release of dissolved organiccarbon (DOC) by the scyphozoan jellyfish Aurelia aurita and its potential influence on the production of planktic bacteria. Mar Biol 121:527-532

- Hasegawa T, Koike I, Mukai H (2001) Release of dissolved organic nitrogen by a planktonic community in Akkeshi Bay. Aquat Microb Ecol 24:99-107

Jørgensen NOG, Jacobsen CS (1996) Bacterial uptake and utilization of dissolved DNA. Aquat Microb Ecol 11: 263-270

> Jumars PA, Penry DL, Baross JA, Perry MJ, Frost BW (1989) Closing the microbial loop-dissolved carbon pathway to heterotrophic bacteria from incomplete ingestion, digestion and absorption in animals. Deep-Sea Res A 36: 483-495

Kornberg A (1995) Inorganic polyphosphate-toward making a forgotten polymer unforgettable. J Bacteriol 177:491-496

Kuparinen J, Leonardsson K, Mattila J, Wikner J (1996) Food web structure and function in the Gulf of Bothnia, the Baltic Sea. Ambio (Spec Rep) 8:13-21

Lampert W (1978) Release of dissolved organic carbon by grazing zooplankton. Limnol Oceanogr 23:831-834

> Lee SH, Fuhrman JA (1987) Relationships between biovolume and biomass of naturally derived marine bacterioplankton. Appl Environ Microbiol 53:1298-1303

Møller EF (2005) Sloppy feeding in marine copepods: preysize-dependent production of dissolved organic carbon. J Plankton Res 27:27-35

Møller EF (2007) Production of dissolved organic carbon by sloppy feeding in the copepods Acartia tonsa, Centropages typicus, and Temora longicornis. Limnol Oceanogr 52:79-84

Møller EF, Nielsen TG (2001) Production of bacterial substrate by marine copepods: effect of phytoplankton biomass and cell size. J Plankton Res 23:527-536

> Møller EF, Thor P, Nielsen TG (2003) Production of DOC by Calanus finmarchicus, C. glacialis and C. hyperboreus through sloppy feeding and leakage from fecal pellets. Mar Ecol Prog Ser 262:185-191
Paul JH, Jeffrey WH, DeFlaun MF (1987) Dynamics of extracellular DNA in the marine environment. Appl Environ Microbiol 53:170-179

Paul JH, DeFlaun MF, Jeffrey WH, David AW (1988) Seasonal and diel variability in dissolved DNA and in microbial biomass and activity in a subtropical estuary. Appl Environ Microbiol 54:718-727

Paul JH, Jeffrey WH, David AW, DeFlaun MF, Cazares LH (1989) Turnover of extracellular DNA in eutrophic and oligotrophic freshwater environments of Southwest Florida. Appl Environ Microbiol 55:1823-1828

Perry MJ (1972) Alkaline phosphatase activity in subtropical central North Pacific waters using a sensitive fluorometric method. Mar Biol 15:113-119

Pertola S, Koski M, Viitasalo M (2002) Stoichiometry of mesozooplankton in N- and P-limited areas of the Baltic Sea. Mar Biol 140:425-434

Roy S, Harris RP, Poulet SA (1989) Inefficient feeding by Calanus helgolandicus and Temora longicornis on Coscinodiscus wailesii-quantitative estimation using chlorophyll type pigments and effects on dissolved free amino acids. Mar Ecol Prog Ser 52:145-153

Sandberg J, Andersson A, Johansson S, Wikner J (2004) Pelagic food web structure and carbon budget in the northern Baltic Sea: potential importance of terrigenous carbon. Mar Ecol Prog Ser 268:13-29

Selig U, Hubener T, Michalik M (2002) Dissolved and particulate phosphorus forms in a eutrophic shallow lake. Aquat Sci 64:97-105

Shuter BJ, Thomas JE, Taylor WD, Zimerman AM (1983) Phenotypic correlates of genomic DNA content in unicellular eukaryotes and other cells. Am Nat 122:26-44

Siuda W, Chróst RJ, Güde H (1998) Distribution and origin of dissolved DNA in lakes of different trophic states. Aquat Microb Ecol 15:89-96

Smith DC, Azam F (1992) A simple, economical method for measuring bacterial protein synthesis rates in seawater using 3H-leucine. Mar Microb Food Webs 6:107-114

Stibor H, Vadstein O, Diehl S, Gelzleichter A and others (2004) Copepods act as a switch between alternative trophic cascades in marine pelagic food webs. Ecol Lett $7: 321-328$

Strom SL, Benner R, Ziegler S, Dagg MJ (1997) Planktonic grazers are a potentially important source of marine dissolved organic carbon. Limnol Oceanogr 42:1364-1374

> Sudo H, Yamada A, Nakamura N, Matsunaga T (1997) Phosphorus accumulation by a marine photosynthetic bacterium Chromatium sp. Biotechnol Lett 19:783-786

Tezuka Y (1990) Bacterial regeneration of ammonium and phosphate as affected by the carbon:nitrogen:phosphorus ratio of organic substrates. Microb Ecol 19:227-238

Titelman J, Riemann L, Sørnes TA, Griekspoor P, Båmstedt U (2006) Turnover of dead jellyfish: stimulation and retardation of microbial activity. Mar Ecol Prog Ser 325:43-58

Turk V, Rehnstam AS, Lundberg E, Hagström A (1992) Release of bacterial DNA by marine nanoflagellates, an intermediate step in phosphorus regeneration. Appl Environ Microbiol 58:3744-3750

- Urban-Rich J (1999) Release of dissolved organic carbon from copepod fecal pellets in the Greenland Sea. J Exp Mar Biol Ecol 232:107-124

Zohary T, Robarts RD (1998) Experimental study of microbial $P$ limitation in the eastern Mediterranean. Limnol Oceanogr 43:387-395

Zweifel UL, Wikner J, Hagström ^̊, Lundberg E, Norrman B (1995) Dynamics of dissolved organic carbon in a coastal ecosystem. Limnol Oceanogr 40:299-305 